\title{
An Interdisciplinary Approach to Developing Innovative Teaching Strategies for Responding to Global Disasters
}

\author{
Jenny L. Jones \\ Karen Smith Rotabi \\ Jason K. Levy \\ Lisa A. Gray
}

\begin{abstract}
This paper summarizes the development of an interdisciplinary Faculty Learning Community (FLC) bringing together the Virginia Commonwealth University, School of Social Work and Government and Public Affairs, Department of Homeland Security to develop an in depth, comprehensive pedagogical approach to the many issues associated with disaster risk reduction. As the title suggests, this is an interdisciplinary team that explores learning and demonstrates learning models. This particular FLC focuses on understanding the antecedent conditions and root causes of disaster events. We explore best practices to prevent, mitigate, and prepare for such events in the undergraduate and graduate curriculum with an emphasis on homeland security and social work. The FLC is an example of a non-traditional educational model providing content on disaster risk, response, and global impact. This particular FLC was committed to bringing together appropriate expertise from the academic setting as well as inviting community members and organizations into the classroom to share the "lived experience" and intuitive knowledge about disaster.
\end{abstract}

Keywords: Globalization, disaster relief, human rights, faculty learning community, interdisciplinary, natural disaster

The impact of the 2010 Haiti earthquake, the Boxing Day 2004 Indian Ocean tsunami, Hurricane Katrina, 9-11, and the Gulf Oil Spill provide painful reminders of the vulnerabilities of communities to disaster risk. These events highlight the fact that natural, health-related, technologic and human-induced disasters are on the rise worldwide, including statistically-probable but unanticipated catastrophes as well as moderate-scale repetitive events. The responsibility of educational programs, including social work and other disciplines to provide opportunities for students to connect global content is magnified during a crisis. Educational programs are struggling with how to infuse already packed curricula with new knowledge and skills related to combating social injustices while responding to environmental devastation. One potential mechanism for addressing this issue is to provide opportunities for students to engage in learning about global injustices outside the traditional classroom setting. This may

\footnotetext{
Jenny L. Jones, MSW, ACSW, Ph.D., is an Associate Professor; Karen Smith Rotabi, MSW, MPH, Ph.D., is an Assistant Professor; and Lisa A. Gray, MSW, LCSW, is a $2^{\text {nd }}$ year doctoral student, all at the Virginia Commonwealth University, School of Social Work. Jason K. Levy, Ph.D., is an Associate Professor of Homeland Security and Emergency Preparedness at Virginia Commonwealth University and Director of the National Homeland Security Project, the Energy Security Policy Research Group and the Undergraduate Research Opportunities Program. The authors would like to acknowledge Jean Andre Constant, MSW and Hilda Chanchavac for giving voice to those affected by disaster in Haiti and Guatemala, respectively. Their testimonies were critically important to making this learning experience real for students. Funding for this FLC was made possible form the Center for Teaching (CTE) at Virginia Commonwealth University. Both the financial and creative support was invaluable.
} 
include bringing those who have experienced disasters into the classroom for testimony in combination with response from experts on disaster and social problems.

This paper summarizes the development of an interdisciplinary Faculty Learning Community (FLC) bringing together the Virginia Commonwealth University, School of Social Work and Government and Public Affairs, Department of Homeland Security to develop an in depth, comprehensive pedagogical approach to the many issues associated with disaster risk reduction. As the title suggests, this is an interdisciplinary approach to exploring learning and demonstrating learning models. This particular FLC focuses on understanding the antecedent conditions and root causes of disaster events and explores best practices to prevent, mitigate, and prepare for such events in the undergraduate and graduate curriculum, with an emphasis on homeland security and social work. The FLC is an example of a non-traditional educational model providing content on disaster risk, response, and global impact. This particular FLC was committed to bringing together appropriate expertise from the academic setting as well as inviting community members and organizations into the classroom to share the "lived experience" and intuitive knowledge about disaster. Ultimately, this increased opportunities for students to learn from enhanced and highly interactive curriculum. The FLC also served as a vehicle for building collaborative partnerships for faculty at the school of social work with academics from across and outside the university.

In order to engage students in this approach to learning in non-traditional classrooms, the partners developed a case study approach to learning. This paper begins with a review of the literature and establishes the case for using new and innovative approaches to learning, including a description of the FLC development and process. We focus primarily on the Haiti earthquake as a case study given its magnitude and because it was a catalyzing event in terms of the FLC development. Also, other subsequent case studies will be highlighted, to include British Petroleum (BP) Oil Spill/Hurricane Katrina Aftermath, and Guatemalan mudslides.

\section{LITERATURE REVIEW}

Recent trends in globalization are a challenge to the social work profession as a whole (Lyons, 2006) and in turn this has created unique pedagogical challenges for disaster preparedness in health and human services curriculum. Social workers practice in an environment where they come in contact with global social injustice frequently and they have "an ethical responsibility to the broader society to promote the general welfare of society, from local to global levels, and the development of people, their communities, and their environments". This expectation is articulated in the National Association of Social Workers [NASW] Code of Ethics, which emphasizes the need for social workers to advocate for living conditions conducive to the fulfillment of basic human needs, promote social, economic, political, and cultural values and institutions that are compatible with the realization of social justice (NASW Code of Ethics, 1999, p. 8). As a result, the goal of educating future social work and human services professionals to respond as ethical and competent practitioners, including advocacy and human rights considerations for vulnerable peoples continues to be challenge. 
As a global profession, social workers should be aware of both the global and local concerns facing our profession (Healy \& Link, 2011; Lyons, 2006). Immigrants, refugees, asylum seekers are only a few of the populations which social work has invested heavily and participatory inclusion of marginalized people in self determination (e.g. planning for and responding to disaster) is a core value for social workers (CookCraig et al., 2010; Nash, Wong, \& Trlin, 2006). Teaching and learning strategies that focus on issues of diversity, globalization and disaster risk reduction in a non-traditional classroom setting provides an opportunity for students to be educated in a " new field of practice” (Cook-Craig et al., 2010, p. 345) with specialized skills at the micro, mezzo, and macro levels that addresses the unique challenges faced by these populations.

Nagy and Falk (2000) stress the education implications of addressing social problems that are caused by international crises and the growing tendency to solve problems by using policy approaches that are the result of an international cross-fertilization of ideas. As such, the study of global social work can better prepare students for working with diverse populations with a variety of social problems, many of experience issues related to social justice dimensions and inequality. This not only includes new and innovative solutions, but also multi-disciplinary approaches to the problems.

As communities continue to struggle while coping with international and national disasters, social work professionals will need to be prepared to address the myriad of issues related to the trauma associated with disasters. The literature on the relationship between disasters and mental health, find that Post Traumatic Stress Disorder (PTSD) was most frequently be observed and PTSD is considered to be "probably the most debilitating psychological disorder that occurs after traumatic events and disasters" (Satcher, Friel, \& Bell, 2007). The stressors associated with disasters and traumatic events are numerous-including special considerations for children (Gammonley \& Dziegielewski, 2006) and often the condition goes unaddressed in the immediate disaster response and later undiagnosed in the long term.

Even simple grief and loss is important for social workers to understand more fully in the case of disasters. Grief and loss can be experienced and expressed in a variety of ways that include physical, emotional, cognitive, behavioral, social, and spiritual dimensions (Corr, Nabe, \& Corr, 2003); also loss of family, loss of status in community, fear (Potocky, 2008); and, violence against women (Enarson, 1999). Often grief and loss behaviors differ across race, gender, ethnicity, and cultural groups thereby creating even greater challenges for delivering competent health and human services.

The frequency and disturbing toll of natural disasters around the world have increased exponentially during the last 30 years (Emergency Disaster Database, 2007). Schools of social work are poised to partner with other disciplines to engage students in practice that combats social justices, confronts human rights abuses, and promotes global citizenship.

\section{BEGINNING WITH HAITI AS A CASE STUDY}

The earthquake that struck Haiti in January 2010 was one of the most devastating moments in the contemporary history of the Americas. Globally, millions witnessed the 
event as outsiders looking in through the lens of international media. Images of dazed and confused Haitians desperately searching for the family and friends among the rubble were profound and deeply troubling. The social justice and human rights dimensions of Haiti's poverty and pre-earthquake infrastructure-including simple and inadequate building codes-became discourse as the news covered the tragedy. For many US citizens, the gross social inequality in this neighboring nation-- poorest of nations in the Western Hemisphere (United States Central Intelligence Agency, 2010) -- became real, in their personal understanding for the first time. A collective shock occurred as consciousness was raised about not only the grief, loss, and trauma, but also the global social stratification and economic inequality in which Haiti is entangled. For many, Haiti became a case study of poverty, globalization, international debt and related social justice dimensions and human rights abuses.

As we searched for a way to put the disaster into perspective, students wanted to know more about Haiti and how to intervene and offer more assistance. The sheer volume of information about Haiti, in the immediate and the aftermath of disaster were difficult for most to digest. And, fundamentally, many were called to action through voluntary donations and other forms of 'helping' as a personal coping mechanism. Most needed a 'debriefing' to process the graphic images seen in the media in order to resolve secondary trauma from bearing witness to the disaster (Cunningham, 2004). Exploring the causes and consequences of Haiti's poverty became a source of discourse on college campuses across the USA.

Recognizing this need, several student groups combined resources to develop an event entitled Forum on the Disaster in Haiti: Early Reflections on Humanitarian Assistance and Beyond held at Virginia Commonwealth University. The event took place within two weeks of the disaster and a key speaker invited to participate was a trained professional social worker (MSW-level) who had recently returned from an emergency trip home to Haiti to search for lost family members. As a guest speaker, the personal and lived experience of this trip to Haiti offered insight into the depth of the tragedy, and was documented as testimony to which a panel of experts responded. Panelists included a social work faculty member, a school of government faculty member, an executive director of a small organization focused on empowerment and development work in Guatemala, and a staff member of Oxfam who joined the panel via video-telephone communication. The overall program was facilitated by faculty members in the school of social work. The students who participated were those involved in sponsoring the event, including the Association of Black Social Workers and an "Americas Interest Group" called "La Milpa." Also, several social work classes joined the event. Finally and importantly, members of the community participated including the director of the local chapter of the American Red Cross. This element of local relevance was an added value because it gave practical solutions for local community for Haitian living locally, and the Red Cross is the leader in disaster assistance.

\section{Review of Panel Discussion}

The key speaker for the event, a Haitian born MSW began with his personal story of losing a brother and sister-in-law in the quake, showing photos of the family home that 
was left in ruin. He had the unfortunate task of searching for the remains of his family lost under the rubble. Talking about this trauma helped the audience understand the transnational relationship between many Haitians living in the USA and the island nation. He reflected on the nation's history of slavery and debt obligations to France in which is well over $50 \%$ of the national budget went to debt repayment (Johnson, 2009). This fact was undoubtedly a surprise to many in the audience and it illustrates economic inequality in a way which is undeniable and brings to bear issues of colonialism in real and pragmatic terms.

The Oxfam America representative talked about her experience on the ground in the nation in the early days and she focused on community capacity and hope. She reflected on the human condition in such extreme circumstances, talking about the public health threats in the make-shift camps for homeless Haitians while reflecting on the many issues, as well as opportunities. Many students were surprised to learn that Oxfam had closed its donation system because they had reached financial saturation in terms of their organizational capacity to respond to the crisis (Personal communication, Coco McCabe March 24, 2010).

A social work faculty member then presented on a policy paper (Rotabi \& Bergquist, 2010) focused on responding to the problems of orphaned and vulnerable children in the nation, emphasizing the importance of preventing human trafficking. Included was the highly publicized attempt to abduct children for intercountry adoption into the USA (Thompson, 2010). Also, Restaveks-- children who are sold into child labor in Haitiwere also discussed with considerations for culture and social class. This particularly complex discussion was framed with the United Nations Alternative Care of Children Agreement (2009), which provides a framework for understanding international standards of child care and protecting orphaned and vulnerable children. Related guidance includes use of institutions for care of children verses family based solutions, all within the value system of the best interests of the child. Further, some guidance is found in this international instrument for disaster situations, including evacuations of children for medical reasons.

Our panelist from the school of government reflected on the bigger picture of disasters, reminding us that responding to disaster is something that all nations must have a plan. The circumstances in Haiti, as underscored, can happen anywhere and we must ask ourselves if we are personally ready here in the USA. Also noted was the fact that the international relief community is being pushed to the limit by the unparalleled intensity, frequency and scale of natural disasters and catastrophes. He recalled that in 2009, 335 natural disasters occurred worldwide, killing 10,655 persons, disrupting the lives of 119 million others, and causing over US\$ 41.3 billion economic damages. Asia accounted for nearly nine-tenths of global reported natural disaster victims and more than a third of total worldwide economic damages (Vos, Rodriguez, Below, \& Guha-Sapir, 2010). These events highlight the fact that natural, health-related and technologic disasters are on the rise worldwide, including statistically-probable but unanticipated catastrophes as well as moderate-scale repetitive events. Finally, the panelist acknowledged that disaster research has made great strides since the pioneering work of disaster behavior (Prince, 
1920) and hazard mitigation (White, 1942); adding, the debate continues over "What is a disaster?” (Quarantelli, 1998).

Our final panelist was a community partner who presented on the colonial history of the island nation, reminding us how US foreign policy has led to significant problems in the neo-colonial era in which global policies continue to enslave the people of Haiti. Comments specific to hope for the Haitian people to be given an opportunity to have a voice in rebuilding their nation with their vision and cultural value system setting the agenda was presented. This particular heart-felt presentation was a good wrap-up to content about global oppression and empowerment.

Finally, students from the social work program enrolled in a Crisis Intervention class, provided comments on their assessment of local resources for disaster intervention. The Wiki page developed by the class for the assignment was also identified, illustrating the use of technology to communicate about disaster and respond appropriately. These students modeled 'learning in action' and their project was open to the audience for further contribution and consideration.

\section{Haiti Disaster a Catalyst for FLC Development}

It should be clarified that this first event was not officially developed as a FLC activity. It was, actually, a catalyst which brought together a group of faculty, students, and community members. This forum was not only a one-time success, but the involved faculty agreed to develop a "Haiti Six Months Later" event in the Fall of 2010. Ultimately, the result was the development of the FLC itself which executed this second event as well as several other case studies over 2010-2011 academic year, including consideration for the important question posed earlier, "what is disaster?"

The learning content specified in the FLC reflected core values of the social work profession: service, social justice, dignity and worth of the person, importance of human relationships, integrity and competence (NASW, 1999). Additionally, the FLC learning activities were in alignment with core competencies outlined in the Educational Procedures and Assessment Standards (EPAS) from the Council on Social Work Education (2008). Seven core competencies reflected in the FLC are: EPAS 2.1.2, apply social work ethical principle to guide professional practice; 2.1.3, apply critical thinking to inform and communicate professional judgments; 2.1.4, engage in diversity and difference in practice; EPAS 2.1.5, importance of advancing human rights and social and economic justice; EPAS 2.1.8, engagement in policy practice to advance social and economic well-being and to deliver effective social work services; and 2.1.9, respond to context that shape practice. These standards were integrated throughout the FLC event described below. See table for summary of core competencies and application of practice behaviors embedded in these disaster education activities.

\section{Haiti Revisited Six Months Later}

This second event "Haiti Revisited Six Months Later" summarized that what was known about the earthquake and subsequent humanitarian and development assistance. Strengths and weaknesses were explored with reflections from many of the same 
panelists and participants from the first event. An enhancement for this particular event was the involvement of undergraduate students in the school of government who were given a class assignment that involved constructing poster presentations, describing the impact and progress of the earthquake on the Haitian people six months later. Those presentations were juried by University faculty, and were later displayed on campus.

The power of this second event was reflective capacity. Also, organizing faculty had more time to actually implement the event. As a result, the student poster assignment was integrated into the activity. For many of the undergraduate students participating, this was a first opportunity to present their work in a large forum, using their voice and creativity to illustrate core concepts and knowledge related to the history of Haiti, earthquakes as a disaster experience, and post-disaster responses.

\section{MUDSLIDES IN GUATEMALA}

Later in the fall of 2010, mudslides in Guatemala became an emergent disaster opportunity for consideration when well over one hundred people perished as a result of heavy rains and resulting mudslides in this Central American nation. Drawing upon the resources from our Haiti FLC, we partnered with the local organization the Highland Support Project to bring to campus one of their community health promoters to present on her lived experience of responding to the mudslides. This particular health promoter, an indigenous woman, was invited to campus to present photographs of the devastation. The focus of the presentation was for her to give personal testimony based on what she saw and experienced in the aftermath of the disaster. The event was structured so that she not only had 'voice', but the concept of self-determination was clear in her presence-our guest speaker was speaking for herself and the indigenous communities that she serves.

This speaker spoke also of the dynamics of help from outsiders, including faith-based approaches which are encroaching upon traditional religious practices and beliefs of Mayan Indians. This particular aspect of the testimony underscored the power and oppression that obstructs self-determination of indigenous peoples as they struggle with poverty and the devastation of disaster. When faith groups seize upon desperation and offer disaster assistance with expectations that long-term relationships and opportunities related to proselytization will be formed, the power to preserve traditional faith beliefs and rituals is at risk if not under attack (Manewal, 2007). Additionally complicating to the issue are elements of colonialism and social stratification which were a part of the discourse given the fact that Guatemala has some of the greatest structural inequality in the Western Hemisphere and indigenous people bear the greatest injustices (United States Central Intelligence Agency, 2012). All of these complex elements were brought together in a powerful testimony of not only despair, but also hope as community resilience was ultimately a critical part of the rebuilding discourse.

\section{GULF COAST OIL SPILL AND THE AFTERMATH OF HURRICANE KATRINA}

Given the recent disasters of the Gulf Coast, the FLC held in the Spring of 2011 focused on the deleterious impact of the BP Oil Spill of the Gulf Coast, while reflecting 
on the devastation caused by Hurricane Katrina. Students and faculty alike participated in a 2.5 hours discussion on the implications of policy and practice on these disasters, with an emphasis on the impact of minority and vulnerable populations. The goal of the event was to elicit discussion on how to improve disaster preparedness in the U.S. and to educate students on existing policies i.e., the Robert T. Stafford Act (2007), and practices that influenced the handling of Hurricane Katrina and the BP Oil Spill. An expert panel of clinicians and policy practitioners were convened to highlight areas specific to mental health symptoms and treatment in children and families, social and economic impact these disasters had on the region, and the lack of communication among policy-makers specific to levels of authority. The discussion specific to policy practice focused on the Robert T. Stafford Disaster Relief and Emergency Assistance Act (2007), Public Law 93288, which highlights provisions of the Act related to Emergency Management and Case Management Services. A limitation of this policy as it relates to the case management feature is there are no guidelines specific to training case managers to practice in a culturally responsive manner. This has major implications for minority populations that are impacted by disaster.

Panelists provided an overview of the two provisions and engaged students in a dialogue about the connection between policy and practice, and how often one shapes the other. Student were encouraged to participate in policy practice to include advocacy via letter writing, making phone calls, coalition building, and grassroots organizing. One of the panelists, a policy professor in the school of social work, engaged participants in a discussion specific to the lack of federal policies in place specific to the handling of Oil Spills (questions were raised around responsibility for clean-up, timeliness of the cleanup, and response to the families affected), all which ultimately impacted the Gulf Coast communities economically, physically and emotionally. Resources specific to federal initiatives to improve conditions for those impacted by these two disasters were also discussed.

The guest panelist from Florida State University, college of social work (via Skype) spoke about changes made to the Stafford Act regarding case management procedures in a natural disaster. Discussed was the provision of case management services after a disaster occurs and the need for culturally competent case management training for social workers that provide such services, particularly in the wake of Hurricane Katrina and the Gulf oil spill. A second guest panelist from the school of social work that specialize in treating trauma in survivors of disaster led the participants in a discussion on best practices for intervention with trauma victims. The discussions referenced the levels of trauma experienced by Hurricane Katrina victims, and drew parallels of grief, loss, displacement, loss of community, and loss of value for those impacted by the oil spill. Participants shared their personal reflections and stories of family and friends impacted by the disasters, reflecting on grief and loss, displacement, health concerns, and lack of communication related to available resources.

Following the panel discussion, the FLC led a segment on a "call for action" which encouraged participants to engage in critical thinking to explore ways in which they could aid their communities in disaster preparedness. This discussion included identifying available resources, locating volunteer opportunities, and engaging in the 
development of new policies and research avenues aimed at increasing social workers response to future disasters.

Table 1: $\quad$ Application of Education Standards to Disaster Response for Haiti Earthquake, Gulf Oil Spill and Guatemalan Mudslides

\begin{tabular}{|c|c|c|c|}
\hline $\begin{array}{l}\text { Human } \\
\text { Rights Issues }\end{array}$ & $\begin{array}{l}\text { Gathering Knowledge \& } \\
\text { Applying Values }\end{array}$ & $\begin{array}{l}\text { Application of Knowledge } \\
\text { and Values }\end{array}$ & $\begin{array}{l}\text { Core } \\
\text { Competencies }\end{array}$ \\
\hline $\begin{array}{l}\text { Haiti: } \\
\text { Alternative care } \\
\text { of children and } \\
\text { child trafficking }\end{array}$ & $\begin{array}{l}\text { Knowledge: } \\
\text { Analysis of orphaned and } \\
\text { vulnerable children/institutional } \\
\text { care } \\
\text { Values: } \\
\text { Importance of kinship care, } \\
\text { culturally relevant care, and } \\
\text { practice of not removing } \\
\text { traumatized children from their } \\
\text { communities }\end{array}$ & $\begin{array}{l}\text { Witnessing testimony of a } \\
\text { Haitian who searched for his } \\
\text { family member's bodies in the } \\
\text { rubble } \\
\text { Use of assessment and social } \\
\text { work values to arrive at a just } \\
\text { and ethical intervention for } \\
\text { orphaned and vulnerable } \\
\text { children. } \\
\text { Critical thinking and discourse } \\
\text { about global social inequality, } \\
\text { extreme poverty, humanitarian } \\
\text { and development assistance in } \\
\text { addition to international debt } \\
\text { load }\end{array}$ & $\begin{array}{l}\text { 2.1.2; 2.1.3; } \\
\text { 2.14; 2.15; } \\
\text { 2.1.8; and } \\
2.1 .10\end{array}$ \\
\hline $\begin{array}{l}\text { Gulf Oil Spill: } \\
\text { Clean water and } \\
\text { work rights } \\
\text { related to } \\
\text { fishing, etc }\end{array}$ & $\begin{array}{l}\text { Knowledge: } \\
\text { Identification of causes and } \\
\text { consequences of deep sea } \\
\text { drilling and connections to } \\
\text { healthy oceans } \\
\text { Values: } \\
\text { Dignity and worth of the person } \\
\text { and social justice }\end{array}$ & $\begin{array}{l}\text { Critical thinking about global } \\
\text { corporate rights over individual } \\
\text { and family rights and social } \\
\text { workers role in response to } \\
\text { economic justice and trauma, } \\
\text { including substance abuse, } \\
\text { unemployment, depression, and } \\
\text { suicide. }\end{array}$ & 2.1.5 and 2.1.9 \\
\hline $\begin{array}{l}\text { Guatemalan } \\
\text { Mudslides: } \\
\text { Indigenous } \\
\text { population } \\
\text { rights in context } \\
\text { of deforestation } \\
\text { \& global rainfall } \\
\text { changes }\end{array}$ & $\begin{array}{l}\text { Knowledge: } \\
\text { Identification of causes and } \\
\text { consequences of environmental } \\
\text { rainfall changes (global } \\
\text { warming). } \\
\text { Values: } \\
\text { Dignity and worth of persons- } \\
\text { especially vulnerable } \\
\text { populations like indigenous } \\
\text { people and their self } \\
\text { determination. }\end{array}$ & $\begin{array}{l}\text { Social planning analysis as } \\
\text { related to effective responses to } \\
\text { environmental derogation in the } \\
\text { context of global warming and } \\
\text { international humanitarian and } \\
\text { development assistance. } \\
\text { Implications for indigenous } \\
\text { populations and the inherent } \\
\text { dilemmas. } \\
\text { Critical thinking about global } \\
\text { corporate rights over individual } \\
\text { and family rights and social } \\
\text { workers role in response to } \\
\text { economic justice and trauma } \\
\text { including, substance, tribal } \\
\text { rights, and depression. }\end{array}$ & 2.14 and 2.19 \\
\hline
\end{tabular}




\section{LESSONS LEARNED}

Disaster resilience has become a topic of intense discussion in the natural resources and policy research communities where resilience is defined as the capacity of a system, community, or society to successfully adapt to extreme events. Hence, a disaster resilient community is able to withstand these external shocks, persist, and rebuild itself when necessary, using the hazards associated with sea level rise and climate change as an opportunity to build back stronger (UN/ISDR, 2002). The resilience concept should be embraced by disaster educators that are working with communities to improve decisionmaking under conditions of uncertainty and rising risk: applications range from "safefail" engineering systems to robust financial instruments (i.e. portfolio hedging) for coping with catastrophe. The most valuable disaster management strategies are robust despite rapid changes in environmental variables and unanticipated outcomes. This emerging and holistic concept of community disaster resilience requires educators to recognize that lives and property can be secured through sustainable local pre- and postdisaster planning in advance of an extreme sea-level event, just as homes raised above the expected flood elevation ("homes on stilts") are better designed than many non-elevated structures to absorb the shock of an inundation event. Disaster resilience can help communities to overcome pathological behavior (including unsustainable livelihoods, institutional rigidity, social dependencies, political hegemony, and ecological degradation) by viewing human culture as embedded within nature; dependent on it, and capable to harm it. However, despite decades of conceptual debates there remain challenges related to the definition and operationalization of disaster resilience, particularly in the context of mitigating and adapting to the impacts of sea-level rise and disaster losses continue to mount.

Bringing these concepts to life in the graduate and undergraduate classroom can best be achieved by:

- Bringing in speakers who could speak in the first person--giving testimony for their experience--was not only moving, but it brought difficult realities into the classroom including grief and loss.

- Using technology which allowed for our panel discussions to be expanded with experts from organizations like Oxfam. This kind of expertise is invaluable and with emerging technology for classroom facilitation, there will be more opportunities for interactive engagement with practicing professionals involved in crisis management, etc.

- Developing an interactive setting which engaged students in a manner that encouraged their use of professional voice, applying social justice and human rights principles to practical application of disaster response including humanitarian and development assistance. 


\section{References}

Cook-Craig, P. G., Craig, C. D., Sossou, M., Moldova, S., Ojha, A., \& Redmon, M. (2010). The process of developing an innovative teaching strategy for promoting international social work. Journal of Global Social Work Practice, 3(2), 1-13.

Corr, C. A., Nabe, C. M., \& Corr, D. M. (2003). Bereavement, grief, and mourning in death-related literature for children. Journal of Death and Dying, 48(4), 337-363.

Council on Social Work Education. (2008). Educational policy and accreditation standards. Retrieved from http://www.cswe.org/File.aspx?id=13780

Cunningham, M. (2004). Teaching social workers about trauma: Reducing the risks of vicarious dramatization in the classroom. Journal of Social Work Education, 40(2), 305-317.

Gammonley, D., \& Dziegielewski, S. F. (2006). Crisis intervention responses to children victimized by terrorism: Children are not little adults. Brief Treatment and Crisis Intervention, 6(1), 22-35. doi:10.1093/brief-treatment/mhj005

Emergency Disaster Database. (2007). The OFDA/CRED international disaster database. Retrieved from Universite Catholique de Louvain website: http://www.em-dat.net

Enarson, E. (1999). Violence against women in disasters: A study of domestic violence programs in the United States and Canada. Violence Against Women, 5(7), 742768.

Healy, L., \& Link, R. J. (Eds.). (2011). Handbook of international social work: Human rights, development, and the global profession. London: Oxford University Press.

Johnson, J. W. (2009). Self-determining Haiti. Ithaca, NY: Cornell University Library.

Lyons, K. (2006). Globalization and social work. International and local implications. British Journal of Social Work, 36(3), 365-380.

Manewal, B. (2007). Religion in the trenches: Liberation theology and evangelical protestantism as tools of social control in the Guatemalan civil war (1960-1966). McNair Scholars Journal, 11(1), 49-62. Retrieved from http://scholarworks.gvsu.edu/mcnair/vol11/iss1/8/

Nagy, G., \& Falk, D. S. (2000). Dilemmas in international and cross-cultural social work education. International Social Work, 43(1), 49-60.

Nash, M., Wong, J., \& Trlin, A. (2006). Civic and social integration: A new field of social work practice with immigrants, refugees, and asylum seekers. International Social Work, 49(3), 345-363.

National Association of Social Workers. (NASW). (1999). Revised by the 2008 NASW Delegate Assembly. Code of Ethics. Washington, DC: Author. Retrieved from http://www.socialworkers.org/pubs/code/code.asp 
Potocky, M. (2008). Immigrants and refugees. In T. Mizzrahi \& L. E. Davis (Eds.) Encyclopedia of Social Work (20 ${ }^{\text {th }}$ ed., Vol. 2, pp. 441-115). Washington, D.C.: NASW Press.

Prince, S. H. (1920). Catastrophe and social change: Based upon a sociological study of the Halifax disaster. Studies in History, Economics, and Public Law, 94, 1-152.

Quarantelli, E. L. (1998) What is a disaster? London: Routledge.

Robert T. Stafford Disaster Relief and Emergency Assistance Act, 42 U.S.C. § 51215207 (2007).

Rotabi, K. S., \& Bergquist, K. J. S. (2010). Vulnerable children in the aftermath of Haiti's earthquake of 2010: A call for sound policy and processes to prevent international child sales and theft. Journal of Global Social Work Practice. Available from http://www.globalsocialwork.org/vol3no1/Rotabi.html

Satcher, D., Friel, S., \& Bell, R. (2009). Natural and manmade disasters and mental health. Journal of the American Medical Association, 298(21), 2540-2542.

Thompson, G. (2010, February 1). Case stokes Haiti's fear for children, and itself. The New York Times. Retrieved from http://www.nytimes.com/2010/02/02/world/ americas/02orphans.html

Vos, F., Rodriguez, J., Below, R., \& Guha-Sapir, D. (2010). Annual disaster statistical review 2009: The numbers and trends. Brussels: CRED.

White, G. F. (1942). Human adjustment to floods: (Research Report No. 29). Chicago: University of Chicago, Department of Geography.

United Nations. (2009). Guidelines for the alternative care of children, Human Rights Council, Eleventh Session Resolution 11/7. Retrieved on February 1, 2010, from http://ap.ohchr.org/documents/E/HRC/resolutions/A_HRC_RES_11_7.pdf

United States Central Intelligence Agency. (2012). The world factbook: Guatemala. Retrieved from https://www.cia.gov/library/publications/the-worldfactbook/geos/gt.html

United Nations Inter-Agency Secretariat of the International Strategy for Disaster Reduction (UN/ISDR). (2002). Living with risk: A global review of disaster reduction initiatives. Retrieved from http://helid.digicollection.org/en/d/Js2653e/

\section{Author note:}

Address correspondence to: Jenny L. Jones, Ph.D., Virginia Commonwealth University School of Social Work, 1001 West Franklin Street, P.O. Box 842027, Richmond, VA 23284-2027. Email: jljones2@vcu.edu 